\title{
Ulla Thøgersen \\ Rousseau vivant: en aktualisering af Émile med fokus på det lidenskabelige fænomenfelt
}

\begin{abstract}
The paper focuses on Rousseau's understanding of passionate life and especially his interpretation of erotic desire in Émile. The main argument presented is that Rousseau by his studies of erotic desire gives us at present day the possibility of radicalizing our understanding of human being in pedagogy. Firstly, by allowing us to rethink passions as important phenomena in human life and secondly, by understanding pedagogical practice as an arena which is part of forming passions, including erotic desire.
\end{abstract}

Nøgleord

Rousseau, lidenskab, det erotiske begrer, betagelse

Tema: Rousseau

\section{Indledning}

En præmis i denne artikel er, at Rousseau - på trods af den tidsmæssige afstand fra den første udgivelse af hans værker til i dag- har noget at sige os. Rousseau er afhængig af sin egen tid, som vi er af vores, men det vil være for hurtigt at afvise Rousseaus aktuelle relevans med denne konstatering. Det gør afstanden mellem Rousseau og os for stor, og en sådan afstand kan hverken bekræftes af Rousseaus værker eller hans placering i aktuelle diskussioner i pædagogisk filosofi. Det virker i stedet mere frugtbart at læse Rousseaus Emile som et muligt bidrag til vore egne forsøg på at begribe væsentlige aspekter ved menneskets tilværelse og de dannelses- og udviklingsprocesser, som denne tilværelse indeholder.'

Det stemmer også overens med Rousseaus fremstilling af sit eget filosofiske projekt som udtryk for et studium af de oprindelige menneskelige dispositioner, hvor disse dispositioner angiver menneskets vilkår (la condition humaine). ${ }^{2}$ Rousseau er som sådan ikke interesseret $\mathrm{i}$ at finde tidstypiske træk ved menneskets tilværelse, men han påpeger, at det vigtigste studium for filosoffen er at klarlægge menneskets natur, dvs. almenmenneskelige

1 Rousseau, Jean-Jacques. Émile ou De l'éducation. (Paris: Gallimard, 1969)/Rousseau, Jean-Jacques. Emile eller om opdragelsen. (København: Borgen, 1997).

2 Rousseau. Emile eller om opdragelsen. (København: Borgen, 1997), 14.

Ulla Thøgersen, e-mail: ulla@learning.aau.dk

Aalborg Universitet, Danmark

Studier i Predagogisk Filosofi | www.ojs.statsbiblioteket.dk/index.php/spf | ISSN nr. 22449140

Årgang 2 | Nr.1 | 2013 | side 34-43 
træk, som må gælde uanset den historiske bevægelse, som det enkelte menneske er del af. Det er ifølge Rousseau først med dette studium, at vi kan forholde os til menneskets naturlige udvikling og derudfra opstille pædagogiske værdisætninger som pejlemærker i forvaltningen af denne udvikling.

Ifølge Høffding 3 indkredser Rousseaus menneskets natur ad tre veje: 1) En teologisk, hvor Rousseau er fokuseret på menneskets natur som Guds værk. Rousseau, som argumenterer for en pædagogisk metode, der værner om den naturlige udvikling og de oprindelige dispositioner, anvender primært den teologiske vej til at argumentere for, at vi må respektere det, som er fra skaberens hånd. Det vil sige, at den menneskelige natur har noget helligt over sig, som skal bevares, ikke destrueres. 2) En naturhistorisk vej, som handler om at beskrive en primitiv, hypotetisk naturtilstand, hvor pointen er, at menneskets udvikling har sin rod i en instinktiv tid, en naturtilstand. Han anvender særligt denne vej til at beskrive menneskets natur i sin rene form, dvs. dens form inden kulturens frembrud og påvirkning. 3) En psykologisk vej, der handler om (selv)iagttagelse af kræfter og drifter, som gør sig gældende i menneskets indre natur. Fokus er på medfødte grundstrukturer, der som sådan er almenmenneskelige.

Med de tre veje forsøger Rousseau at sige noget alment om menneskets natur - og et element i denne indkredsning handler om at begribe det lidenskabelige liv som et væsentligt fænomenfelt i den menneskelige tilværelse. Det er dette lidenskabelige fænomenfelt, der har denne artikels interesse. Det overordnede argument, som skal udfoldes i artiklen, er, at Rousseau med sit studium af menneskets lidenskaber giver os mulighed for at nuancere og radikalisere forståelsen af det menneskelige subjekt, som pædagogikken grundlæggende drejer sig om. For det første i forhold til overhovedet at medtænke lidenskaben som et væsentligt fænomen i menneskets tilværelse og for det andet i forhold til at betragte pædagogikken som et projekt, der er med til at danne eller styre lidenskaben.

Artiklen fremsætter på den baggrund to argumenter: For det første, at Rousseau siger noget væsentligt om det lidenskabelige fænomenfelt, som er afgørende i forhold til at forstå denne side af menneskets tilværelse. I dette argument vil fokus især være på det erotiske begær, herunder at Rousseau indlejrer begæret i en relationel forbindelse, hvor begæret også bliver sat i oplevelsen af en tiltrækning, en betagelse af en anden. Det vil sige, at begæret er knyttet til en emotionel oplevelse af andethed og som sådan også må ses som et responsivt fænomen. Denne forståelse åbner vores blik for en side af menneskets tilværelse, der ikke kan beskrives inden for en forklaringsramme, der har fokus på henholdsvis behov eller uligevægt i en oplevelse af uoverensstemmelse. For det andet peger Rousseau igennem denne karakteristik af det erotiske begær på, at begæret ikke blot er en medfødt disposition, der følger en iboende logik, men at begæret i høj grad er præget af en kulturel styring, f.eks. knyttet til en kulturel værdisætning af, hvad der findes tiltrækkende. Det medfører et spørgsmål, som vedrører pædagogikken: Hvordan forvaltes begær inden for en bestemt

3 Høffding, Harald. Jean-Jacques Rousseau og hans filosofi. (København: Det nordiske forlag, 1896), 93-94. 
kultur? Der foregår en organisering af det erotiske begær igennem samfundets værdier og adfærdsnormer, hvor disse værdier og normer også er fastholdt i en pædagogisk praksis. Rousseau forholder sig dermed til spændingen mellem natur og kultur, mellem det almene og det specifikke, mellem disposition og dannelse, og gør på den vis det lidenskabelige liv, derunder det erotiske begær, til et pædagogisk tema

I den forstand understøtter Rousseau også aktuelle bestræbelser på at rehabilitere begær og lidenskab som et pædagogisk tema ${ }^{4}$ Denne aktuelle bestræbelse er kendetegnet ved, at den på den ene side sigter på at nuancere vores forståelse af den menneskelige eksistens ud fra et fokus på lidenskab og begær og på den anden side søger at forankre den pædagogiske teori og praksis i en sådan nuanceret forståelse.

Denne artikel følger en grundlæggende argumentation, som også er blevet formuleret $i$ to tidligere arbejder, ${ }^{5}$ dog sætter denne artikel $\mathrm{i}$ højere grad fokus på det erotiske begær - og på Rousseaus bidrag i forhold til fremherskende litteratur inden for det læringsteoretiske felt, herunder behovsteorier og konstruktivistiske teorier. Artiklen er i sin videre udformning inddelt i to afsnit, der uddyber de to hovedargumenter, hvor hovedvægten er lagt på forståelsen af det lidenskabelige fænomenfelt, derunder det erotiske begær.

\section{Det lidenskabelige fænomenfelt}

I Émile er grundlaget et begreb om den medfødte selvopretholdelsesdrift. ${ }^{6}$ Med afsæt i denne drift er mennesket $i$ et forhold til verden, der handler om at tilfredsstille nødvendige behov med det formål at bevare sit liv. Selvopretholdelsen er ifølge Rousseau udtryk for en grundlæggende lidenskab, selvkærligheden (amour de soi). Denne selvkærlighed er en primitiv lidenskab, der knytter mennesket til sig selv i et ønske om at bevare sit eget liv, og den udtrykker sig dermed som en drift til at ville eksistere. Det er en drift, der styrer vores handlinger og retter os mod verden. Den medfødte selvkærlighed er en befaling fra naturen, og alle menneskets dispositioner såsom vores kropslige styrke, fornuft og vores forestillingsevne skal ifølge Rousseau fungere som støtte til selvopretholdelsen. Det er den grundlæggende præmis i hans pædagogiske værdisætninger. Selvkærligheden kan ifølge Rousseau balanceres af andre følelser og af fornuften, men den kan også fordærves af et

4 Se f.eks. Burch, Kerry T. Eros as the Educational Principle of Democracy. (New York: Peter Lang Publishers, 2000); Garrison, Jim. Dewey and Eros: Wisdom and Desire in the Art of Teaching. (New York: Teachers College Press, 1997); Garrison, Jim. Walt Whitman and John Dewey on Democracy and Eros. (København: Forskningsprojektet: Voksenuddannelse, folkeoplysning og demokrati, arbejdspapir nr. 12, 1999). Kelly, Ursula A. Schooling Desire. Literacy, Cultural Politics and Pedagogy. (New York: Routledge, 1997); Liston, Daniel et Jim Garrison (eds.). Teaching, Learning and Loving, Reclaiming Passion in Educational Practice. (New York: RoutledgeFalmer, 2004); Thøgersen, Ulla. Det lidenskabelige menneske. (Aalborg: Aalborg Universitetsforlag, 2011) og Todd, Sharon (ed.). Learning Desire. Perspectives on Pedagogy, Culture and the Unsaid. (New York: Routledge, 1997).

5 Se Thøgersen, Ulla (2010a). "Begær som pædagogisk tema - en læsning af Rousseau's Émile". Nordisk Pedagogik 30 (2010) og Thøgersen, Ulla. Det lidenskabelige menneske. (Aalborg: Aalborg Universitetsforlag, 2011).

6 Rousseau, Jean-Jacques. Émile ou De l'éducation. (Paris: Gallimard, 1969)/Rousseau, Jean-Jacques. Emile eller om opdragelsen. (København: Borgen, 1997). 
socialt spil, derunder en søgen efter anerkendelse og ære, hvormed selvkærlighed forskyder sig til egenkærlighed. I egenkærligheden styres vores handlinger ud fra ønsket om at være bedre end andre. Egenkærlighedens drivkraft er egoismen, og den grundlægger ifølge Rousseau unyttige lidenskaber knyttet til en stræben efter besiddelse og nydelse.

Denne opdeling mellem selvkærlighed og egenkærlighed betyder, at Rousseau indlejrer to forskellige fænomener i det lidenskabelige felt. For det første den naturlige lidenskab, som han vurderer som nødvendig, hvor denne lidenskab kobler sig til en forståelse af behov som eksempelvis sult og tørst, og bliver en forklaringsramme for, hvorfor vi tilfredsstiller vores behov. Den naturlige lidenskab, selvkærligheden, og de nødvendige behov er med til at sikre en biologisk opretholdelse. Den indsætter en afhængighed i vores tilværelse, men en afhængighed af ting (mad, drikke etc.), ikke af andre mennesker. Den enkelte kan derfor bevare en selvstændighed fra det sociale liv, fordi de nødvendige begær er begrænsede, og mennesket har de nødvendige kræfter til selv at kunne tilfredsstille sine behov. For det andet de sociale lidenskaber, som overskrider det naturlige og kobler sig på en social logik og "vækker" begæret efter anerkendelse og magt. De sociale lidenskaber er ifølge Rousseau udtryk for unødvendige begær, der baserer sig på forestillingsevnen og ønsket om en egoistisk nydelse. Forestillingsevnen strækker vores mål længere, end vore kræfter kan føre os, og ender med fortvivlelsen. De begær, forestillingsevnen vækker, er mangfoldige, og de indsætter sig - som f.eks. begær efter anerkendelse og magt - i relation til en social logik og indfører dermed en afhængighed af andre.

Denne skelnen er velkendt hos Rousseau og står som en nøgle til hans pædagogik. Pædagogikken skal værne om selvkærligheden, en naturlig sanselighed, og bremse egenkærligheden, den sociale pervertering af den naturlige sanselighed. Umiddelbart kunne man ledes til at tro, at denne skelnen fører Rousseau til et argument om, at det lidenskabelige fænomenfelt samlet set består af to grundlæggende fænomener. Denne todeling af det lidenskabelige fænomenfelt bliver dog sprængt, når Rousseau studerer det erotiske begær. Det lidenskabelige fænomenfelt består ikke blot af to former for lidenskab, en naturlig, der kan ses som en indre grundstruktur i menneskets natur, og en social, der er relateret til ydre indtrængende omstændigheder, men også af erotisk begær, der overskrider en skelnen mellem det naturlige og det sociale.

I Émile beskriver Rousseau det erotiske begær ud fra udtrykket "menneskets anden fødsel". ' Der er med andre ord igen tale om en befaling fra naturen. I puberteten finder der en kønsudvikling sted, som betyder, at en erotisk lidenskab bliver bragt i spil. Der er tale om en særlig trang, en naturlig disposition, som mennesket i udgangspunkt ikke kan undslippe; men til forskel fra selvkærligheden er det erotiske begær rettet mod den anden. Trangen er forbundet med et ønske om at knytte sig følelsesmæssigt og seksuelt til et andet menneske. Begærets dynamik er på mange måder knyttet til den andens tilstedeværelse og måde at være på. På den vis er det sociale afgørende for det erotiske begær. Denne begærsform

7 Rousseau, Jean-Jacques. Emile eller om opdragelsen. (København: Borgen, 1997), 124. 
bryder dermed logikken med to forskellige lidenskabelige fænomener: de naturlige og de sociale. Kimen til det erotiske begær er at finde i menneskets iboende natur, men begæret "vækkes" også af en anden, der dermed binder mennesket til det sociale liv og ikke lader den enkelte hvile i sin egen selvstændighed og uafhængighed.

I grunden er det erotiske begær unødvendigt set i forhold til selvkærlighedens sigte på selvopretholdelse, dvs. individets bevarelse, men det er afgørende i forhold til artens bevarelse, og derfor har Rousseau brug for at finde plads til erotikken og forstå, hvordan det erotiske begær kan virke inden for det sociale, kulturelle liv. ${ }^{8}$ Rousseau beskriver, at begæret i puberteten først er uden mål. Det er ikke en bestemt anden, der er begærets genstand, men der er en rastløshed over det. På et tidspunkt vil begæret dog føre til et valg af en bestemt anden. Der vil være tale om, at man foretrækker en anden, og derigennem kan begæret fikseres. Dette valg foregår ifølge Rousseau uden en egentlig opmærksom mod valget. Det kan derfor synes spontant, naturligt eller blindt, men det forudsætter en slags stillingtagen, der henviser til en forståelse af menneskets fortrin og skønhed. Denne forståelse er i høj grad præget af de kulturelle omgivelser og den offentlige mening.

Rousseau trækker her i en retning, der vægter den enkeltes valg og dermed den enkeltes frihed $\mathrm{i}$ forhold til en bestemmelse af begærets genstand, men omvendt begrænser han også denne frihed i forhold til de kulturelle omgivelser, som er med til at sætte (normmæssige) betingelser for valget. Derudover forekommer det paradoksalt at tale om et valg, da det ikke er klart rationelt bestemt, men tværtimod foregår det uden en egentlig opmærksomhed. Der vælges, uden at man egentlig ved, at man vælger. Rousseau taler om, at valget er forankret $\mathrm{i}$ en emotionel tiltrækning af den anden. Den anden kan være til stede på en sådan måde, at jeg bliver betaget af den anden, på en sådan måde, at det synes, at den anden "vækker" mit begær, helt uden jeg selv har taget stilling, endsige netop valgt denne særlige anden. Rousseaus pointe er dog, at denne betagelse, som synes spontan, stadigvæk er forankret ind i givne forestillinger om skønhed og fortrin - og dermed er det forskelligt fra menneske til menneske, hvem de (vælger at) tiltrækkes af, afhængigt af kulturelle omgivelser og opdragelse.

De kulturelle omgivelser præger ikke blot begæret i dets frembrud rettet mod en bestemt anden, men der er heller ikke en givet determinisme i selve begærets dynamik. Tværtimod præges begæret i sin bevægelse rettet mod den anden af forskellige aspekter, for eksempel andre følelser, som ledsager begæret. Er begæret eksempelvis knyttet til medlidenhed og ømhed, så det medfører et ønske om et gensidigt forhold, eller er det koblet til egenkærlighed og havesyge, så begæret udtrykker et ønske om erobring? Ifølge Rousseau er det afgørende at balancere begæret ud fra en mådeholdende tålmodighed (tempérance) og en medlidenhed (pitié). ${ }^{9}$ Her finder han en pædagogisk opgave: at dyrke disse dyder for at sikre en ansvarlig indstilling $i$ begærets bevægelse.

8 Se også Thøgersen, Ulla. Det lidenskabelige menneske. (Aalborg: Aalborg Universitetsforlag, 2011).

9 Wivel, Peter. Rousseau. Fantasien til magten. (København: Gyldendal, 1998), 335. 
Et interessant forhold ved Rousseaus beskrivelser af det erotiske begær er, at han peger på begæret som et relationelt fænomen, der samtidig er udtryk for en naturlig disposition og en emotionel oplevelse af den anden. På den vis gør hans begærsbegreb op med adskillelsen mellem indre og ydre og mellem natur og kultur - da begæret på samme tid er en givet disposition i mennesket og et responsivt fænomen. På baggrund af fænomenologisk filosofi har jeg fremsat et lignende argument angående begærets træk, hvor jeg fra et fænomenologisk perspektiv argumenterer for, at begæret er udtryk for en almenmenneskelig disposition, men det oprinder relationelt i en respons til et følelsesmæssigt kald i oplevelsen af en tiltrækkende andethed..$^{10}$ Det vil sige, at begæret begynder ved det oplevede, ved det begærede - og begæret må nødvendigvis adskilles fra både behov og en ren viljesakt. Begær er ikke en givet behovstilstand i den menneskelige organisme, men jeg kan heller ikke producere eller fremtvinge et begær ved at sige "jeg vil begære X". Begæret opstår spontant i oplevelsen og kan på denne måde også virke overrumplende eller ubelejligt. Det vil sige, at der er en passivitet i begær: Det rammer mig. Denne forståelse placerer begærets begivenhed i selve oplevelsen som en respons til det oplevede. Oplevelsen former en værensmåde, der er en forandring af min situation: Jeg bliver et begærende subjekt. På denne måde er begær ikke produceret af iboende subjektive strukturer alene, men begæret er en begivenhed, vi træder ind i. I denne begivenhed er der et kald. Begæret fordrer, at jeg tager begæret op som en dynamik rettet mod det begærede. Det er ikke nok for begæret at eksistere som en "urolig" krop, men begæret er altid ude over sig selv i den forstand, at begæret stræber efter at relatere sig til det begærede. Begær kan derfor siges at motivere mine handlinger, fordi det indfører en præference eller værdidimension i min eksistens baseret på den oplevede tiltrækning af det begærede.

Med dette argument om begærets træk er der væsentlige forskelle fra Rousseau, da han ikke vil betone, at begæret som sådan begynder ved oplevelsen af den anden. Begæret for Rousseau begynder med kønsudviklingen og udtrykker sig først i en rastløshed uden for en relation til den anden. Rousseau betoner i højere grad befalingen fra naturen, som er knyttet til begæret. Derudover er der også en forskel i forhold til spontaniteten. Rousseau fastholder, at relationen er sat i et valg af den begærede, om end dette valg kan synes spontant. Der er tale om en bedømmelse, en vurdering, men en vurdering, man slet ikke selv ved, at man foretager. Med mit argument er der ikke som sådan tale om et valg, men betoningen er snarere på, at noget rammer én. Rousseau er dog også med på dette responsive aspekt, når han taler om den emotionelt forankrede tiltrækning, betagelsen, som den enkelte kan opleve - og derudover er der et fælles træk i selve forståelsen af betagelse. Hvor et behov, f.eks. sult eller tørst, forankrer sig i en mangeltilstand, hvor man må rette sig mod verden for at sikre en tilfredsstillelse ved at "fylde" sin mangel, så er betagelsen snarere forankret i

10 Se Thøgersen, Ulla. Om begæer. Filosofiske refleksioner relateret til det pæedagogiske felt. (Ph.d.-afhandling, Det Humanistiske Fakultet, Aalborg Universitet, 2007.) og Thøgersen, Ulla (2010b). "Desire as response to experience: reflections on motivational aspects of learning". In Communication, collaboration and creativity. Researching adult learning, ed. M. Horsdal, .Odense: University Press of Southern Denmark, 2010. 
"et emotionelt overskud". Når jeg oplever den anden som tiltrækkende, knytter det sig ikke til en oplevet mangel, men til den meningsfylde, som denne oplevelse allerede udtrykker.

Hvis vi ser på fremherskende litteratur inden for det læringsteoretiske område, der egentlig sigter på samme formål som Rousseau, at beskrive menneskets natur, så er det lidenskabelige og det erotiske ikke et område, der fylder meget. Rousseaus beskrivelser giver på den baggrund mulighed for at nuancere vores forståelse af menneskets handlinger. Set i relation til to overordnede tendenser i litteraturen kommer Rousseau med et andet bud på, hvordan mennesket også er til stede i verden:

For det første: En del "klassisk" litteratur tager udgangspunkt i et begreb om behov som det motiv, der knytter mennesket til verden og dermed også til den anden. Dette udgangspunkt ser vi for eksempel hos Maslow ${ }^{11}$ og McClelland, ${ }^{12}$ der begge betragter motivation som behovstilfredsstillelse. Maslow beskriver, hvordan et behov melder sig som en mangeltilstand. Denne tilstand engagerer subjektet i en situation, som kan betyde, at manglen forsvinder, dvs. behovet tilfredsstilles. Maslow taler om bestemte faktorer, som generelt motiverer mennesket: fysiologiske behov, behov for sikkerhed, kærlighed, anseelse og selvaktualisering. McClelland ser på lignende faktorer, men med fokus på behov for accept, præstation og magt. Denne tradition deler et synspunkt med Rousseau i forhold til den naturlige side i mennesket med et fokus på de naturlige behov, hvor prototypeeksemplet er tørst og sult - men Rousseau overskrider samtidig denne behovsforklaringsramme. Med sit begreb om lidenskab peger han blandt andet på det emotionelle overskud, som kan ligge i en betagelse af den anden, hvor denne tankegang overskrider mennesket som et væsen, der er i mangel. Vi er ikke blot "wanting animals", men også lidenskabelige væsener, der responderer til verden i begær.

For det andet: Et fællesstræk for konstruktivistisk litteratur inden for det læringsteoretiske område synes derimod at være, at de indlejrer "motivet"13 til menneskets læring i en oplevelse af en eller anden form for uoverensstemmelse (forstyrrelse, mismatch, uligevægt), hvor læringen får karakter af en form for korrektion. Det vil sige, at udspringet for læring - i modsætning til behovstankegangen - placeres tydeligere i et samspil med omgivelserne. Denne form for litteratur peger på at det ikke blot er "menneskets egen indre natur", der kalder os til handling, men i høj grad vores samspil med verden omkring os. Dette ser vi eksempelvis i systemisk orienterede teorier, hvor læring initieres i feedback fra omgivelserne og som en form for forstyrrelse og korrektion. ${ }^{14}$ Også Piaget kan med sit begreb om ekvilibium placeres inden for denne forståelse: menneskelivet er rettet mod ligevægt i samspillet med omgivelserne og læring er udtryk for den udlignende aktivitet, der genetablerer

11 Maslow, A.H. Motivation and Personality. (New York: Addison Wesley, 1954).

12 McClelland, D.C. The Achieving Society. (Princeton: Van Nostrand, 1961).

13 I den forstand er det egentlig misvisende at tale om et 'motiv', da der ikke er tale om et subjektivt givet motiv, der går forud for en interaktion, men interaktionen føder så at sige en grund til handling.

14 Se f.eks. Bateson, G. "De logiske kategorier for læring og kommunikation". In Fra laringens horisont, edited M. Hermansen. Aarhus: Klim, 1998. 
en ligevægt i en assimilativ og akkomodativ proces. ${ }^{15}$ Trods andre forskelle finder vi grundlæggende samme opfattelse hos Argyris og Schön, der beskriver læring som en korrektion af mismatch mellem forventninger og handlinger. ${ }^{16}$ Inden for denne ramme kan motivation betragtes ud fra et "eksistentielt krav" om at opretholde en overensstemmelse (match eller balance) mellem forventninger og handlinger, da selve motivationen tager form som et "behov" til at reetablere en overensstemmelse. Dette "behov" er med andre ord ikke personforankret i psykiske mekanismer, men er udtryk for en interaktionsform, hvor pointen her er, at denne interaktionsform frembringer en dynamik. I en overordnet kategorisering af denne form for teorier kan man sige at læring konstant finder sted på opfordring af omgivelserne. Dette perspektiv adskiller sig fra teorier, der forstår læringens udspring i iboende subjektive drivkræfter. Der er et fokus på de interaktive aspekter knyttet til menneskets væren, men en særlig form for interaktion knyttet til en oplevelse af en eller anden form for uoverensstemmelse, der igen skal bringes i balance. Det lidenskabelige eller mere generelt det emotionelle har ingen synderlig plads som afsæt for handling og læring. Her tilbyder Rousseau et blik, da han netop sætter fokus på, at en interaktion med verden ikke kun er grundlagt i et naturligt givet behov eller i en oplevelse af uoverensstemmelse, men der kan også være tale om en form for emotionelt overskud, en lidenskabelig betagelse, som sætter os i bevægelse.

Med andre ord: Hos Rousseau kobles både en forståelse for det iboende i mennesket, menneskets natur og derudover er der et fokus på, at interaktionen med verden er af central betydning, derunder at verden i denne interaktion kan have et "tvingende" aspekt. Verden kan i den forstand trænge sig på som en forstyrrelse og stille sig an som en fordring om at genetablere en orden, en ligevægt. På den vis er der fællesskab med den ovennævnte litteratur, men derudover understreger han i endnu større grad end de to forståelsesrammer fremhævet ovenfor, at mennesket grundlæggende er et lidenskabeligt væsen - og han peger på, at lidenskaben ikke skal forstås inden for en ramme, der handler om behov eller en oplevelse af uoverensstemmelse, men ud fra tanken om et emotionelt overskud. Oplevelsen af betagelse stiller sig hverken an som en fordring om at tilfredsstille en oplevet mangel eller som en oplevet uoverensstemmelse, hvor det handler om at korrigere sine handlinger for at genfinde en overensstemmelse eller ligevægt. Betagelsen sætter et begær ind $i$ en relation til den anden og stiller sig an med en fordring om at knytte sig følelsesmæssigt til den anden, at opbygge et forhold med den anden. Der er tale om en emotionel bevægethed. Der er med andre ord tale om en anden fænomentype end både behovet og den instrumentelle korrektion af en uoverensstemmelse. Rousseau har på den vis et nuanceret og mangfoldigt blik for de fænomenfelter, som præger os og er med til at bestemme

15 Piaget, J. Ligevagtsbegrebets rolle i psykologien In: Illeris, K. (red.) (2000): Tekster om læring. Roskilde: Roskilde Universitetsforlag, 2000.

16 Argyris, C., \& D.A. Schön. Organizational Learning. A Theory of Action Perspective. (New York: Addison-Wesley, 1978) og Argyris, C. and D.A. Schön. Organizational Learning 2: Theory, Method and Practice. (New York: AddisonWesley, 1996). 
vores retning i verden - og især hans fokus på lidenskaben giver os mulighed for at radikalisere vores forståelse af det menneskelige subjekt, som pædagogikken helt grundlæggende handler om.

\section{Pædagogik som styring af lidenskab}

Hos Rousseau samler en forståelse af menneskets lidenskab sig samtidig ud fra to aspekter: den iboende natur og det ydre påtrængende, herunder det sociale spil. På den vis kombinerer han også filosofien og pædagogikken i et forsøg på både at beskrive grundlæggende træk ved lidenskaben og tage værdimæssigt stilling til, hvordan begæret bør forvaltes inden for rammerne af en kultur. Det fører videre til næste argument, der peger på, at pædagogikken også er et projekt, der er med til at danne lidenskaben, og på den vis er det lidenskabelige liv et væsentligt pædagogisk tema.

Med det erotiske begær kan vi tale om et eksistentielt vilkår eller en grundlæggende betingelse i menneskets tilværelse. Det er ikke det samme som at sige, at der er en neutralitet eller iboende logik forbundet med begærets udfoldelse. Jeg er altid et konkret menneske, der forholder mig til verden ud fra en individuel stil eller holdning, hvor denne holdning igen hænger sammen med de samfundsmæssige, kulturelle forhold, vi også indgår i. Rousseau har fokus på alle tre faktorer knyttet til det lidenskabelige fænomenfelt: det almenmenneskelige (naturlige), det individuelle og det kulturelle. Han indfanger på den vis det lidenskabelige fænomenfelt inden for rammerne af en konstant spænding mellem specificitet og generalitet, mellem individualitet og subjektivitet. Et spændingsforhold, der betyder, at vi aldrig fuldt ud kan kende det konkrete begær, før det er udlevet, men samtidig kan vi - ud fra filosofien eller psykologien-forsøge at udpege nogle træk, der må gælde, når vi har en oplevelse af begær. Det er denne spænding, der betyder, at Rousseau fører filosofien sammen med pædagogikken. Rousseaus indkredsning af menneskets natur bidrager til pædagogikken, fordi pædagogikken er rettet mod mennesket og forudsætter en forståelse af mennesket, som det grundlæggende forsøger at (ud)danne. Pædagogikken kan omvendt bidrage til filosofien og psykologien ved at rette blikket mod den sociale og kulturelle styring af begærets udtryk og de historiske variationer i udfoldelsen af begær. Denne styring er mulig, fordi begæret også har en "plasticitet", dvs. det har træk, som kan formes kulturelt og ændres historisk blandt andet i kraft af forskellige pædagogiske tilgange.

Fra Rousseaus perspektiv står den pædagogiske formning ikke i modsætning til det almene, til begærets stabile eller naturlige træk. En modsætning vil være forankret i en forestilling om enten-eller, men det betyder, at et både-og overses. Forestillingen om både-og peger på, at et fænomen både kan have dynamiske træk, der tydeligvis præges af kultur og historie, og stabile naturlige træk, der fastholder en væsentlighed i begær og peger på det almenmenneskelige. Begær er en grundlæggende menneskelig erfaring, da alle mennesker kan begære, men samtidig er det også et dannet eller formet fænomen. Når vi taler om det almene, så betyder det derfor ikke, at historiens prægninger af begæret afvises. 
På baggrund af Rousseaus overvejelser er det muligt at fremsætte en forståelse af pædagogikken som en arena, hvor begæret "styres". Denne tankegang finder vi også hos Kelly, som skriver i Schooling Desire, at pædagogikken handler om at producere et subjekt, der deltager i den offentlige sfære på en bestemt måde. ${ }^{17}$ Den kulturelle politik sætter rammerne for "det bestemte", altså hvilke konkrete værdier, der skal være styrende i det offentlige liv. Pædagogikken er den praksis, der forsøger at føre disse kulturelle værdier ud i livet. Kelly pointerer at pædagogikken dermed også udfolder sig som styring af begær, af det lidenskabelige fænomenfelt, da dens praksis også omfatter at få subjektet til at begære på en bestemt måde, så den kan anerkendes af den kulturelle politik. Kelly argumenter for, at aktuelle pædagogiske diskussioner sjældent tematiserer pædagogik på den vis, da der er en tendens til at betragte mennesket som et de-erotisk væsen. ${ }^{18}$ Hun oplever, at det er en provokation at tale om pædagogikken ud fra et fokus på begær. Dermed overses nemt en diskussion af, hvordan begæret virker i menneskets liv, og hvordan den pædagogiske praksis forvalter dette.19 Her giver Rousseau os et blik, da han fra begyndelsen tematiserer mennesket som et lidenskabeligt, begærende væsen - og samtidig betragter pædagogikkens praksis som en kulturelforankret værdibaseret styring af lidenskaben. Rousseau kan på den vis bidrage til en form for pædagogisk radikalisering, fordi hans filosofi fremskriver en menneskeforståelse, der synliggør det lidenskabelige fænomenfelt. Samtidig argumenterer han for, at pædagogikken - forstået som en værdimæssig ramme om menneskets tilværelse udfolder sig som en styring af det lidenskabelige liv; om vi er opmærksomme på det eller ej.

Når vi tænker på, hvor væsentlig lidenskaben er i vores tilværelse - vi behøver blot tænke på en forelskelse, der i sit virke fylder en stor del af ens horisont - så synes det afgørende, at pædagogikken også formår eksplicit at tematisere denne side af menneskets liv og derigennem forholde sig til, hvilke værdier der virker ind på lidenskaben. Når Émile skal vejledes til at følge en naturlig udvikling, så er det brændende punkt netop dannelsen af det erotiske, det lidenskabelige.

17 Kelly, Ursula A. Schooling Desire. Literacy, Cultural Politics and Pedagogy. (New York: Routledge, 1997).

18 Kelly, Ursula A. Schooling Desire. Literacy, Cultural Politics and Pedagogy. (New York: Routledge, 1997), 24-25.

19 Se også Thøgersen, Ulla. Det lidenskabelige menneske. (Aalborg: Aalborg Universitetsforlag, 2011), 9ff. 